\title{
THE INFLUENCE OF THE INFLATION RATE AND THE INTEREST RATE OF BANK INDONESIA CERTIFICATES ON THE COMPOSITE STOCK PRICE INDEX WITH THE US DOLLAR EXCHANGE RATE AS A MODERATING VARIABLE ON THE INDONESIA STOCK EXCHANGE
}

\author{
Dwi Septiani \\ Universitas Pamulang \\ dosen01075@unpam.ac.id
}

\begin{abstract}
This study aims to determine how the influence of the inflation rate and the interest rate of Bank Indonesia Certificates (SBI) on the Composite Stock Price Index (IHSG) with the US dollar exchange rate as a moderating variable on the Indonesia Stock Exchange 2007-2016. The data of this research consists of inflation rate reports, Bank Indonesia Certificate interest rate reports, US dollar exchange rate reports and reports on the Composite Stock Price Index for 120 (one hundred and twenty) months, starting from 2007 to 2016. The research method in this research is associative research with quantitative data analysis. Data calculation was performed by using multiple regression analysis of the relationship, $t$ test, $F$ test and the coefficient of determination $R 2$. Meanwhile, to test the moderating variable using the interaction test. The inflation rate variable (X1) and the interest rate for Bank Indonesia Certificates (SBI) (X2) with the US dollar exchange rate $(X 3)$ as the moderating variable simultaneously have a positive and insignificant effect on the Composite Stock Price Index (IHSG) (Y) on the Stock Exchange. Indonesia 2007-2016. The coefficient of determination of 0.596065 means it is known that the influence of the inflation rate variable (X1) and the interest rate for Bank Indonesia Certificate (SBI) (X2) with the US dollar exchange rate (Z) as the moderating variable is $59.61 \%$ while the rest $40.39 \%$ is explained by other variables that are not explained and examined in this study
\end{abstract}

Keywords: Inflation Rate, Bank Indonesia Certificate Interest Rate, US Dollar Exchange Rate and Composite Stock Price Index

\section{INTRODUCTION}

The capital market is one of the places (media) that provides investment opportunities for individual and institutional investors. Therefore, the direction and magnitude of the capital market movement is an interesting topic for academics and market practitioners to study it. The Composite Stock Price Index (IHSG) is one of the stock market indices used by the Indonesia Stock Exchange (IDX).

* Corresponding author's e-mail: dosen01075@unpam.ac.id http://openjournal.unpam.ac.id/index.php/EAJ 
The capital market plays an important role in the Indonesian economy, where the IHSG value can be a leading economic indicator in a country. The index movement is strongly influenced by investors' expectations on the condition of both national and global fundamentals. The existence of new information will affect investors' expectations which will ultimately affect the IHSG.

Broadly speaking, there are 3 (three) main factors that influence the IHSG movement, namely: domestic factors, foreign factors and factors of capital flows to Indonesia. Domestic factors are the fundamental factors of a country such as inflation, national income, the amount of money in circulation, interest rates, political turmoil, and the exchange rate of the rupiah. These various fundamental factors are considered to have an effect on investors' expectations which in turn will affect the movement of the Index.

If the inflation rate increases, the IHSG price level will decrease further. This is because with the high rate of inflation, company profits will decrease. So that investors do not want to invest,

\section{LITERATURE REVIEW \\ 2.1 Inflation}

Inflation is a situation and condition in which the price of goods has increased and the value of the currency has weakened. If this condition occurs continuously, it will have an impact on the worsening of the overall economic conditions as well as shocks to the political stability of a country (Fahmi, 2015). Inflation is the change in prices in the aggregate. Development will run smoothly if inflation can be kept as low as possible.

The condition for inflation is that there is an increase in prices generally this will cause the IHSG price to decline.

The development of the average rupiah exchange rate against the dollar is indirectly related to the inflation rate and the interest rate issued by Bank Indonesia. Investors usually use the interest rate as a benchmark for comparison to invest. Generally, the interest rate has a negative relationship with the stock market. This is because the increase in interest rates results in investors preferring to save their money in the bank rather than choosing to invest in the stock market, which causes stock prices to decline. In determining investment options, macroeconomic factors have empirically proven to have an influence on investment development in several countries.

The focus of this study is the effect of inflation and SBI interest rates on the IHSG in Indonesia (with the US dollar exchange rate as a moderating variable). The adoption of these three factors is not caused by those three factors which are suspected of having an influence on changes in share prices in Indonesia, but rather the suspicion that these three factors have a very dominant influence on changes in share prices.

and continuously. If only one or two types of goods increase, it is not inflation. Temporary increases in prices, for example increases in prices due to seasonality, before holidays, objects and so on, are not referred to as inflation.

\subsection{Bank Indonesia Certificate Interest Rates}

BI rate according to Bank Indonesia is a policy interest rate that reflects the monetary policy stance or stance set by Bank Indonesia and announced by the public (www.bi.go.id). The interest rate can be one of the guidelines for investors in returning investment

* Corresponding author's e-mail: dosen01075@unpam.ac.id

http://openjournal.unpam.ac.id/index.php/EAJ 
decisions in the capital market. As an alternative vehicle for investment, the capital market offers a return at a certain level of risk.

Based on the explanation above, it can be concluded that the interest rate is the price obtained from the use of investment funds in a certain period time.

\subsection{US Dollar Exchange Rate}

The foreign exchange rate is the exchange rate of foreign exchange against the rupiah (Manurung, 2016). The foreign exchange can be in the form of hard currency or other currencies. The Indonesian people remember more about the foreign exchange rate in the form of the US dollar exchange rate. So, it can be concluded that the rupiah exchange rate is a comparison between the currency value of one country and another.

\subsection{Composite Stock Price Index}

The Composite Stock Price Index (IHSG) is one of the stock market indices used by the Indonesia Stock Exchange (IDX). The stock price index is a stock price index number that has been compiled and calculated in such a way as to produce a trend.

The increase in the stock price index shows the market is in a state of excitement. The unchanged stock price index indicates a stable situation, while the stock price index has decreased, indicating market conditions are showing sluggishness. IHSG calculations are carried out every day, namely after the close of trading every day. In the near future, it is hoped that the IHSG calculation can be done several times or even in a few minutes, this can be done several times or even in several minutes, this can be done after the automated trading system is implemented properly.

\section{RESEARCH METHOD 3.1.Population and Sample}

The population in this study is the inflation report, Bank Indonesia Certificate interest rate, US dollar exchange rate and the Composite Stock Price Index from each year. The sample is part of the number and characteristics of the population (Sugiyono, 2014). Nonprobability sampling is a sampling technique that does not provide equal opportunities for every element or member of the population to be selected as a sample. Nonprobability sampling sampling technique used in this study.

The sampling method used was purposive sampling, namely the sampling technique with special considerations. In this case, the particular consideration is the period of observation or financial statements that are most recent or 10 years back. The sample in this study is the inflation report, SBI interest rate, US dollar exchange rate and IHSG from 20072016.

\subsection{Operational Definitions of Variables}

The variables in this study consisted of the dependent variable, the independent variable and the moderating variable. The dependent variable is the variable that is described or influenced by the independent variable. The dependent variable in this study is the Composite Stock Price Index (IHSG). Independent variables are variables that explain or influence other variables. The independent variables in this study are the Inflation Rate and the Interest Rate on Bank Indonesia Certificates (SBI). Moderating variables are variables that can strengthen or weaken the relationship between the independent variable and the dependent variable.

* Corresponding author's e-mail: dosen01075@unpam.ac.id

http://openjournal.unpam.ac.id/index.php/EAJ 


\subsection{Data Types and Sources}

The data in this study are secondary data. According to Sugiyono (2010), secondary data is a data source that does not directly provide data to data collectors, for example through other people or through documents. Secondary data obtained from internal companies are inflation rate, Bank Indonesia Certificate interest rate, US dollar exchange rate and Composite Stock Price Index from January 2007 to December 2016. Meanwhile, secondary data obtained from external companies is literature study to strengthen the writing of this article.

\subsection{Data Analysis Techniques}

Statistical data processing has a very important role in a study because from the results of data processing we will get research conclusions. Data processing techniques include the calculation of data analysis research models (Andriyanto, Effriyanti, \& Hidayat, 2018). Before making conclusions in a study, an analysis of data must be carried out so that the research results are accurate. So this research was conducted using statistical methods assisted by the Eviews 8 program.

This research was conducted with the aim of knowing the relationship between the independent variable Inflation Rate and SBI Interest Rate with the IHSG as the dependent variable with the US Dollar Exchange Rate as a moderating variable. This study uses multiple linear regression analysis. Multiple regression analysis is used to predict how far the value of the dependent variable $(\mathrm{Y})$ will be if the independent variable $(\mathrm{X})$ is changed. According to Sugiyono (2012), explaining that regression analysis is used to predict how the value of the dependent variable changes when the independent variable is increased or decreased in value.

Because in this study using multiple regression analysis, it is necessary to test the assumptions implied in multiple regression analysis to meet the BLUE (Best Linear Unbias Estimate) criteria. The classic assumption test in this study includes multicollinearity, heteroscedasticity, autocorrelation and normality tests.

\section{RESULTS AND DISCUSSION}

\subsection{Results}

\subsubsection{Normality Test}

Table 1: Normality Test

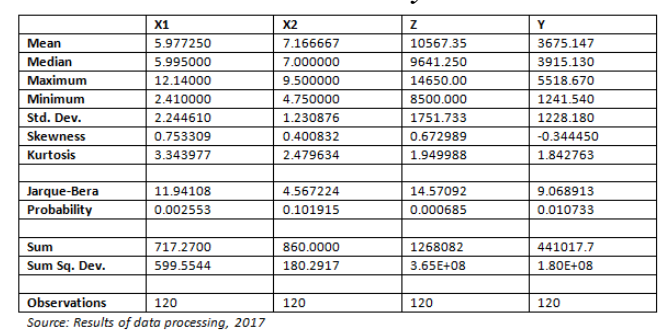

Based on the Jarque-Bera value which is above 2 (meaning significant) or a probability of more than $5 \%(0.05)$, it can be seen that the $\mathrm{x} 2$ variable is normally distributed.

\subsubsection{Multicollinearity Test}

To test multicollinearity using the Eviews 8 program. If you have an equation with two independent variables, then you have to run the regression twice as well, with each analysis using one independent variable as the dependent variable. Following are the results of the analysis if $y$ is the dependent variable and the variables X1 and $\mathrm{X} 2$ are the independent variables.

* Corresponding author's e-mail: dosen01075@unpam.ac.id 


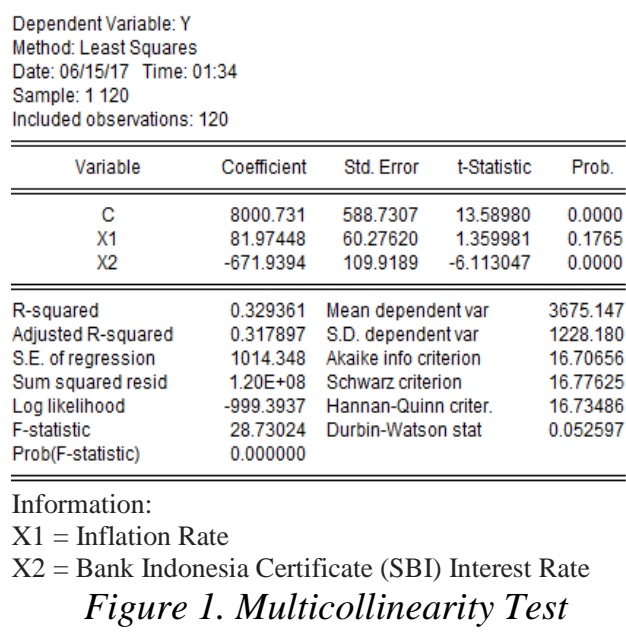

\subsubsection{Heteroscedasticity Test}

To test Heteroscedasticity using the Eviews 8 program and the method used is the graph method (Hidayat, 2020). The following are the results of heteroscedasticity testing with the following graphic methods:

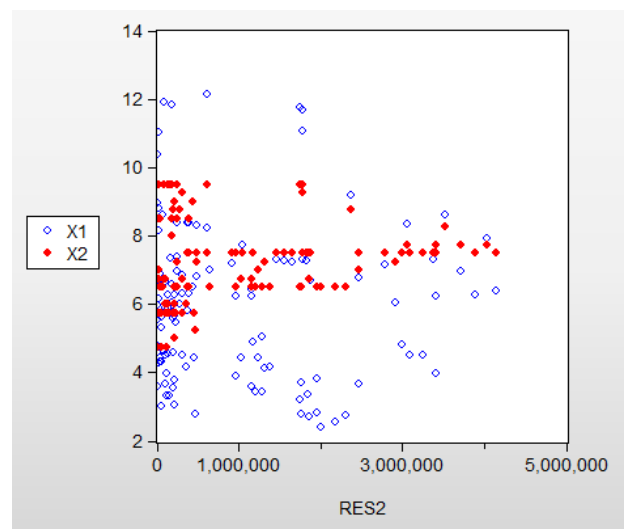

Figure 2. Scatter Plot

The scatter plot above shows that the data is randomly distributed and does not show a certain pattern, so it can be assumed that there is a heteroscedasticity problem.

\subsubsection{Autocorrelation Test}

To test autocorrelation using the Eviews 8 program and using the DurbinWatson test. Following are the results of Information: autocorrelation testing using the Durbin-

Watson test:

Dependent Variable: $Y$

Method: Least Squares

Date: 06/15/17 Time: 02:27

Sample: 1120

Included observations: 120

\begin{tabular}{lrlll}
\hline \hline \multicolumn{1}{c}{ Variable } & Coefficient & Std. Error & t-Statistic & Prob. \\
\hline \hline C & 8000.731 & 588.7307 & 13.58980 & 0.0000 \\
X1 & 81.97448 & 60.27620 & 1.359981 & 0.1765 \\
X2 & -671.9394 & 109.9189 & -6.113047 & 0.0000 \\
\hline \hline R-squared & 0.329361 & Mean dependent var & 3675.147 \\
Adjusted R-squared & 0.317897 & S.D. dependent var & 1228.180 \\
S.E. of regression & 1014.348 & Akaike info criterion & 16.70656 \\
Sum squared resid & 1.20 E+08 & Schwarz criterion & 16.77625 \\
Log likelihood & -999.3937 & Hannan-Quinn criter. & 16.73486 \\
F-statistic & 28.73024 & Durbin-Watson stat & 0.052597 \\
Prob(F-statistic) & 0.000000 & & & \\
\hline
\end{tabular}

The DW statistical value is 0.052597 . The DW statistic value lies in the Reject area H0 which means there is no autocorrelation.

\subsubsection{Determination Coefficient Test $\left(\mathbf{R}^{2}\right)$}

From the results of the calculation of the regression analysis between the inflation rate (X1) and the SBI interest rate $(\mathrm{X} 2)$ on the $\mathrm{JCI}(\mathrm{Y})$, the R-squared is 0.329261. The amount of the correlation coefficient of 0.329261 is equal to $32.93 \%$. This figure explains that $32.93 \%$ is the use of the Inflation Rate and Bank Indonesia Certificate Interest Rate (SBI) variables. While the remaining $67.07 \%$ must be explained by other causative factors.

Meanwhile, from the results of the calculation of the regression analysis between the inflation rate (X1) and the SBI interest rate (X2) against the IHSG (Y) with the US Dollar Exchange Rate (Z) as the moderating variable, the Rsquared is 0.596065 . The magnitude of the correlation coefficient of 0.596065 is equal to $59.61 \%$ as the use of the Inflation Rate and Bank Indonesia Certificate Interest Rate (SBI) variable and the US Dollar Exchange Rate as the moderating variable. While the remaining $40.39 \%$ must be explained by other causative factors.

$\mathrm{X} 1$ = Inflation Rate

$\mathrm{X} 2=$ Bank Indonesia Certificate (SBI) Interest Rate

* Corresponding author's e-mail: dosen01075@unpam.ac.id 
Figure 3. Autocorrelation Test

The DW statistical value is 0.052597 . The DW statistic value lies in the Reject area $\mathrm{H} 0$ which means there is no autocorrelation.

\subsubsection{F Test}

Based on the calculation of the inflation rate variable $(\mathrm{X} 1)$ and the $\mathrm{SBi}$ interest rate (X2) against the JCI (Y)

\subsection{Discussion}

Based on the results of regression analysis testing that the effect of the inflation rate and the interest rate of Bank Indonesia Certificates (SBI) on the Composite Stock Price Index (IHSG) with the US Dollar Exchange Rate as the moderating variable indicates that the value of Fcount> Ftable (42.42473> 2.68). This shows that the inflation rate and the interest rate for Bank Indonesia Certificates (SBI) have a positive and insignificant effect on the Composite Stock Price Index (IHSG) with the US dollar exchange rate as a moderating variable. Meanwhile, the R-Squared value was obtained at 0.596065 . The magnitude of the correlation coefficient of 0.596065 is equal to $59.61 \%$. This figure explains that there is an influence of $59.61 \%$ between the inflation rate and the interest rate for Bank Indonesia Certificates (SBI) on the Composite Stock Price Index (IHSG) with the US dollar exchange rate as a moderating variable. While the rest, which is $40.39 \%$, must be explained by other causative factors which are not explained and examined in this study.

So, the first R-squared value from the calculation of the effect of the inflation rate and the SBI interest rate on the JCI is 0.329261 or $32.93 \%$, while after the second equation rises to 0.596065 or $59.61 \%$. So in conclusion, the existence of the US Dollar Exchange Rate with the US Dollar exchange rate (Z) as the moderating variable, the Fcount value is 42.42473> Ftable 2.68 which means the Inflation Rate and Interest Rate Bank Indonesia Certificates (SBI) and the US Dollar Exchange Rate as moderating variables have a simultaneous effect on the Composite Stock Price Index (IHSG) and with a significant value of $0.2062>0.05$.

strengthens the relationship between the Inflation Rate and the Bank Indonesia Certificate Interest Rate (SBI) on the Composite Stock Price Index (IHSG).

So, the inflation rate and the interest rate for Bank Indonesia Certificates (SBI) have a positive and insignificant effect on the Composite Stock Price Index (IHSG) with the US Dollar Exchange Rate as a moderating variable. This is not in accordance with previous research by Dwi Maryani (2011), Divianto (2013) and Anak Agung Gde Aditya Krisna, et al (2013). This may occur because in this study the variable of the US dollar exchange rate is a moderating variable where the value of the US dollar exchange rate in this study strengthens the relationship between the inflation rate and the interest rate of Bank Indonesia Certificates (SBI) to the Composite Stock Price Index (IHSG). However, investors are still waiting for other factors (apart from inflation, interest rates on Bank Indonesia Certificates (SBI) and the US dollar exchange rate) to make their investment decisions.

\section{CONCLUSION}

Based on the test results above, it can be explained that with the US Dollar Exchange Rate $(Z)$ as a variable that moderates the relationship between the Inflation Rate (X1) and the Bank

* Corresponding author's e-mail: dosen01075@unpam.ac.id

http://openjournal.unpam.ac.id/index.php/EAJ 
Indonesia Certificate Interest Rate (SBI) (X2) on the Composite Stock Price Index (IHSG).

For future researchers with similar topics to conduct further studies by including other independent variables, such as the Hang Seng stock index, the Dow Jones Industrial Average stock index, gross domestic product, unemployment rate, foreign exchange reserves and external factors originating from abroad. such as: world economic

\section{REFERENCES}

Andriyanto, R., Effriyanti, E., \& Hidayat, A. (2018). The Effect of Spiritual Intelligence (SQ) and Personality Types on Auditor's Ability to Detect Fraud. JABI (Jurnal Akuntansi Berkelanjutan Indonesia), 1(3), 258-268.

Divianto. (2013). Analisis Pengaruh Tingkat Inflasi, Tingkat Suku Bunga SBI dan Nilai Kurs Dollar AS (USD) terhadap Indeks Harga Saham Gabungan (IHSG) di Bursa Efek Indonesia, Politeknik Sriwijaya

Fahmi, I. (2015). Manajemen Investasi, Edisi 2. Jakarta: Salemba Empat.

Hidayat, A. (2020). Pengaruh penggunaan aplikasi eviews terhadap kemampuan pemecahan masalah dan hasil belajar statistik. MAJU: Jurnal Ilmiah Pendidikan Matematika, 7(1), 18-24.

Hidayat, R. R., Hilya, L. \& Darminto. (2014). Pengaruh Tingkat Suku Bunga, Tingkat Inflasi, Nilai Kurs Dollar dan Indeks Strait Times terhadap Indeks Harga Saham Gabungan (Studi pada Bursa Efek Indonesia growth, oil prices, gold prices and others.

Conclusions should answer the objectives of research and/ or scientific findings. Do not repeat from results and discussion, but should summarize the findings. If needed, describe more things to do correlated to the research. Conclusions should be in $11 \mathrm{pt}$ Times New Roman.

periode Januari 2010 - Juni 2013, Fakultas Ilmu Administrasi - Universitas Brawijaya Malang

Manurung, A. H. (2016). Cadangan Devisa dan Kurs Valuta Asing, Penerbit: Buku Kompas.

Manurung, M. \& Pratharma R. (2008).

Pengantar Ilmu Ekonomi (Mikroekonomi \& Makroekonomi), Edisi Ketiga, Penerbit: Fakultas Ekonomi Universitas Indonesia.

Maryani, D. (2011). Pengaruh Inflasi, Kurs dan Tingkat Suku Bunga SBI terhadap Indeks Harga Saham Gabungan di Bursa Efek Indonesia, MM-UNS

Sugiyono. (2010). Metode Penelitian Bisnis, Cetakan ke-15, Bandung: Alfabeta.

Sugiyono. (2011). Metode Penelitian Kuantitatif Kualitatif Dan $R \& D$, Cetakan ke-14, Bandung: Alfabeta.

Sugiyono. (2012). Statistika Untuk Penelitian, Bandung: Alfabeta.

Sugiyono. 2014. Metode Penelitian Pendidikan Pendekatan Kuantitatif, Kualitatif, dan R\&D. Bandung: Alfabeta. 